$\mathrm{Nr} 6$

WARSZAWA-

KRAKÓw 2003

\author{
STANISŁAW SALA
}

Akademia Świętokrzyska, Kielce

\title{
Wybrane cechy dzialalności korporacji transnarodowych i ich implikacje dla Polski
}

Jedną z cech szczególnych współczesnych systemów gospodarczo-politycznych jest szeroko rozumiana niepewność. Dotyczy ona wielu dziedzin życia, począwszy od bezpieczeństwa publicznego poprzez stabilizację zawodową, aż do perspektyw rozwoju na przyszłość. Za główną przyczynę zmian uważa się procesy globalizacji, których głównym motorem napędowym oraz głównymi beneficjentami są korporacje transnarodowe (KTN) (Gwiazda 2000, Zorska 2000).

\section{ROZWÓJ I ZNACZENIE KORPORACJI TRANSNARODOWYCH}

Rozwój korporacji transnarodowych sięga XIX wieku i jest bezpośrednio związany $\mathrm{z}$ postępem $\mathrm{w}$ transporcie, technikach przechowywania produktów oraz sposobach zarządzania. Po II wojnie światowej wraz ze wzrostem stabilizacji politycznej zaczęła bardzo szybko wzrastać liczba i znaczenie działających w gospodarce światowej korporacji transnarodowych. W wyniku wzrostu znaczenia procesów związanych z umiędzynarodowieniem przedsiębiorstw i produkcji, KTN dysponują bardzo dużym kapitałem produkcyjnym i technologicznym generującym olbrzymie zyski. Korporacje transnarodowe dysponuja ogromną siłą ekonomiczną, na którą składają się przede wszystkim duża wartość sprzedaży oraz dysponowanie nowoczesną technologią i wykwalifikowaną siłą roboczą. O potędze świadczy fakt, że niejednokrotnie dochody KTN przekraczają wartość PKB średnio rozwiniętych krajów (tab. 1). O sile korporacji nie trzeba nikogo przekonywać, wystarczy wspomnieć, że 52 korporacje transnarodowe zaliczane są do 100 największych gospodarek funkcjonujących na świecie (Bielawski 2000). Szacuje się, że obecnie działa około 60 tys. korporacji transnarodowych dysponującymi ponad pół miliona filiami, które łącznie zatrudniają ponad 6 mln pracowników (World Investment Report 1999). Wartość dochodów 15 największych korporacji transnarodowych na świecie w 2000 roku przedstawia tabela 1. Bardzo duży potencjał korporacji przyciąga uwagę poszczególnych krajów do tego stop- 
nia, że prześcigają się one w stwarzaniu jak najkorzystniejszych warunków dla lokowania kapitału na ich terenie (Thurow 1999).

Tabela 1. Największe korporacje na świecie w 2000 r. (wg uzyskiwanych dochodów)

\begin{tabular}{|c|l|l|l|c|}
\hline Lp. & \multicolumn{1}{|c|}{ Nazwa korporacji } & Kraj pochodzenia & \multicolumn{1}{c|}{ Branża } & $\begin{array}{c}\text { Dochody } \\
\text { (mld USD) }\end{array}$ \\
\hline 1. & Exxon Mobil & USA & motoryzacyjna & $210,392.0$ \\
\hline 2. & Wal-Mart Stores & USA & handlowa & $193,295.0$ \\
\hline 3. & General Motors & USA & motoryzacyjna & $184,632,0$ \\
\hline 4. & Ford Motor & USA & motoryzacyjna & $180,598.0$ \\
\hline 5. & Daimler Chrysler & USA & motoryzacyjna & $150,069.7$ \\
\hline 6. & Royal Duch/Shell Group & Wlk. Bryt./ Holandia & motoryzacyjna & $149,146.0$ \\
\hline 7. & BP & Wlk. Brytania & paliwowa & $148,062.0$ \\
\hline 8. & General Electric & USA & elektryczna & $129,853.0$ \\
\hline 9. & Mitsubishi & Japonia & motoryzacyjna & $126,579.4$ \\
\hline 10. & Toyota Motor & Japonia & motoryzacyjna & $121,416.2$ \\
\hline 11. & Mitsui & Japonia & handlowa & $118,013.7$ \\
\hline 12. & Citigroup & USA & bankowa & $111,826.0$ \\
\hline 13. & Itochu & Japonia & handlowa & $109,756.5$ \\
\hline 14. & Total Fina Elf & Francja & paliwowa & $105,869.6$ \\
\hline 15. & Nippon Telegraph \& Telephoe & Japonia & telekomunikacyjna & - \\
\hline
\end{tabular}

Źródło: „Fortune” 2001

\section{EKSPANSJA KTN w POLSCE}

Korporacje transnarodowe są obecne na rynku polskim już od dłuższego czasu. Jednak w czasach gospodarki centralnie planowanej ich aktywność była ograniczona do działalności pośredniej. Na naszym rynku Centrala Handlu Zagranicznego i PEWEX zajmowały się dystrybucją zachodnich towarów. Ponadto KTN mogły wchodzić w spółki z mniejszościowym pakietem. Sytuacja zmieniła się diametralnie wraz z upadkiem systemu komunistycznego. Uruchomiony proces transformacji systemowej umożliwił ich ekspansję.

Skalę ekspansji obrazuje wartość zagranicznych inwestycji bezpośrednich (ZIB) (ryc. 1), która zaczęła wzrastać w latach dziewięćdziesiątych, osiągając maksymalną wartość w 2000 roku. Od tego czasu obserwujemy spadek strumienia ZIB do nieco ponad 7000 dol. USA

w 2001. Prawdopodobnie wynika to między innymi ze spadku liczby prywatyzowanych firm (ryc. 2). Uwzględniając strukturę geograficzną, główne strumienie ZIB płyną z Fran- 
cji, USA, Niemiec, Holandii oraz Włoch. W 2000 roku ok. 91\% inwestycji zagranicznych w Polsce pochodziło z krajów Triady, w tym 73\% z krajów europejskich (Durka 2001).

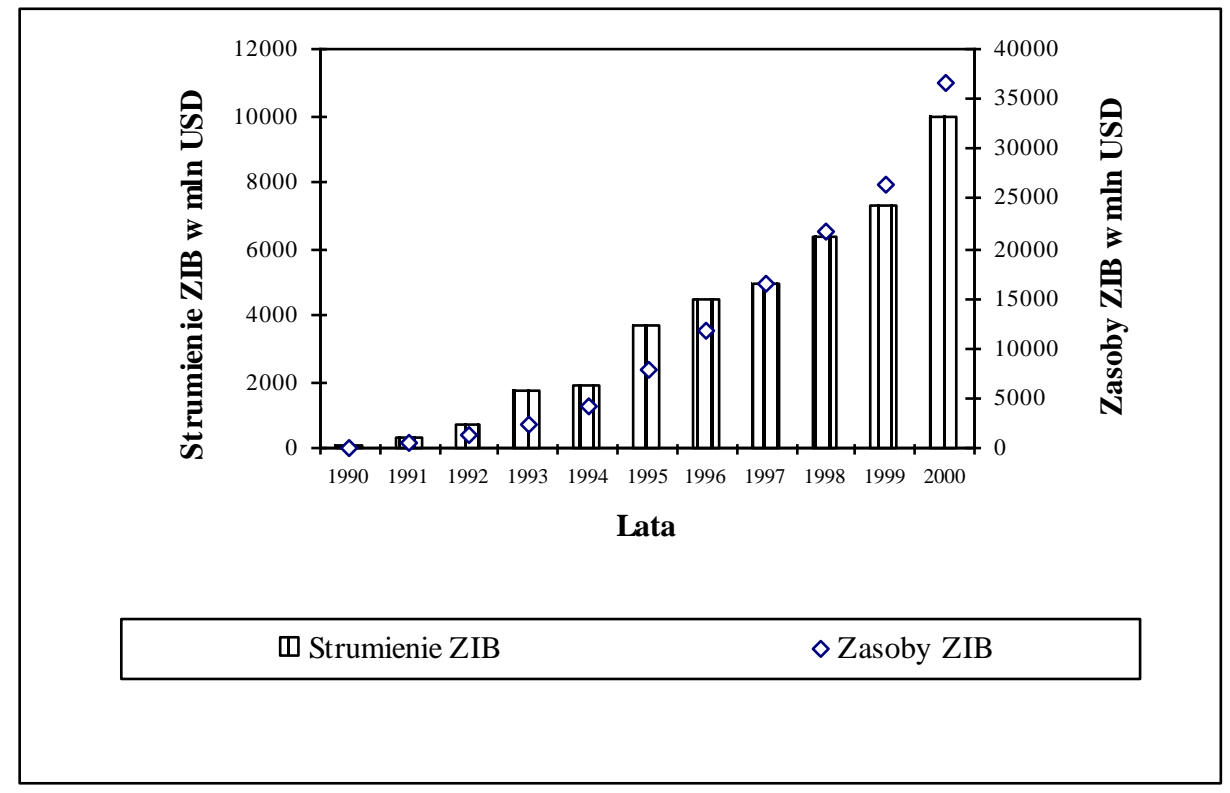

Ryc. 1. Napływ zagranicznych inwestycji bezpośrednich do Polski w latach 1990-2000

Źródło: Opracowanie własne na podstawie World Inwestment Report

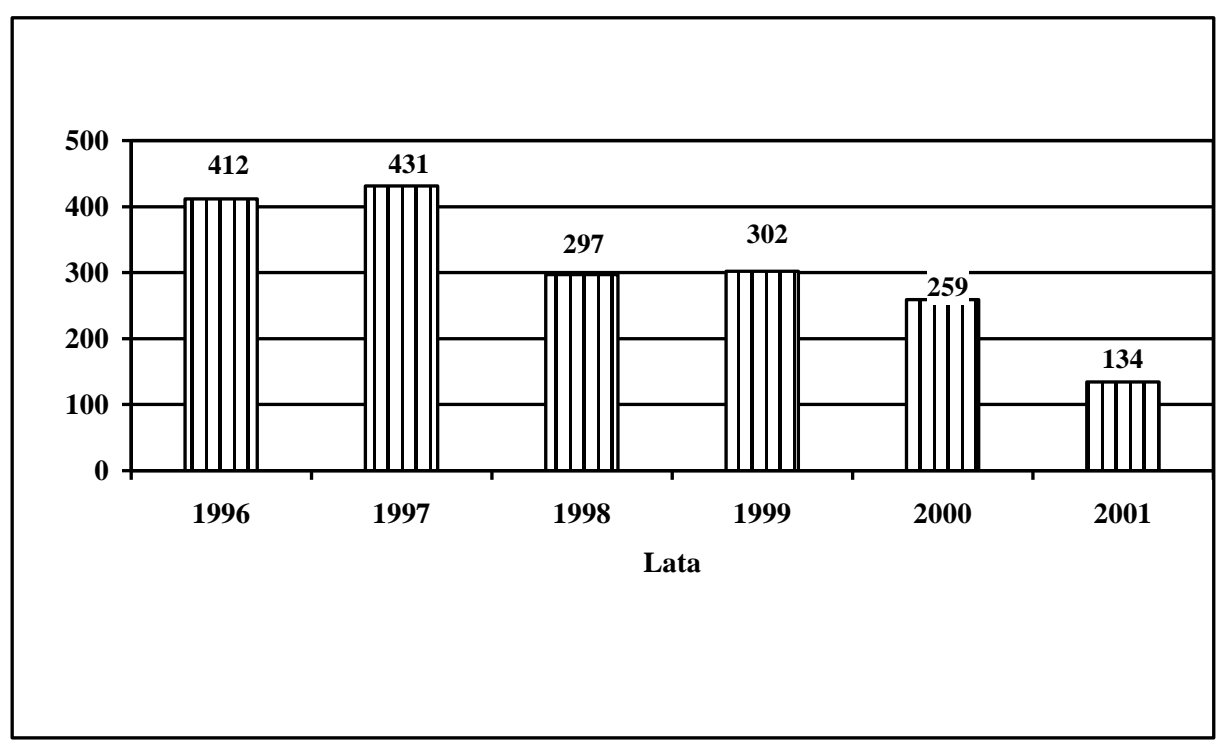

Ryc. 2. Liczba sprywatyzowanych firm państwowych w wybranych latach Źródło: Opracowanie własne na podstawie: „Polityka” nr 16, 2002. 


\section{WYBRANE CECHY ORAZ KONSEKWENCJE DZIAŁALNOŚCI KTN w POLSCE}

Do głównych cech działalności KTN można zaliczyć:

- sprzyjanie „wirtualnej ekonomii”,

- lokowanie procesu produkcji tam gdzie najtaniej,

- zdolność do szybkiej zmiany profilu produkcji,

- zwiększenie elastyczności poprzez zmianę charakteru dostaw - prefabrykatów, półproduktów i usług wg systemu just in time,

- wykorzystywanie siły roboczej wg systemu just in time worker,

- wyrównywanie warunków działania w skali światowej,

- integrowanie działalności przedsiębiorstw i gospodarek,

- powszechne stosowanie cen transferowych.

Wzrost znaczenia wirtualnej ekonomii stwarza nie tylko rozdźwięk między sferą finansową a gospodarczą, ale także powoduje zwiększoną podatność Polski na kryzys finansowy. Obecna siła wirtualnej ekonomii jest tak duża, że jest ona w stanie w bardzo krótkim czasie doprowadzić do bankructwa praktycznie każdy kraj, niezależnie od jego pozycji gospodarczej. Wirtualna ekonomia nie tylko zmniejsza produkcyjne zastosowanie kapitału, ale także pozbawia rząd możliwości wpływania na gospodarkę kraju.

Doskonałym przykładem lokowania produkcji tam gdzie najtaniej jest niedawna rywalizacja między Czeskim Kolinem a Dabrową Górniczą o inwestycje Toyoty. W marcu 2001 roku dotarła do Ministerstwa Gospodarki informacja dotycząca możliwości budowy w Polsce fabryki samochodów. W ostatecznym rozrachunku wytypowano Kraków, Dąbrowę Górniczą i Radomsko, z tym, że oferta Dąbrowy była najkorzystniejsza. W celu zachęcenia inwestora Dąbrowa Górnicza zaproponowała: zakup terenu pod inwestycję w cenie 1 euro za całość (ok. 200 ha), sfinansowanie budowy domków jednorodzinnych dla części zagranicznej kadry, przygotowanie szkół i przedszkoli z językiem angielskim dla kadry, pokrycie kosztów przeszkolenia pracowników, wstęp wolny do klubu golfowego w Siemianowicach oraz inne drobne atrakcje. Jednak oferta okazała się zbyt mała. Porównywalną propozycję złożyli Czesi z Kolina, którzy w sumie zaoferowali inwestorowi 200 milionów euro. Widzimy więc, że korporacje lokują produkcję nie tylko tam gdzie taniej, ale także tam gdzie im się więcej zapłaci.

Lokowanie produkcji tam gdzie najtaniej było jedną z głównych przyczyn zainteresowania korporacji Polską w latach 90. Początkowo w działalności korporacji przeważał kierunek nastawiony na zapełnianie luki podaży, a w drugiej połowie lat 90 . zaczęła dominować koncepcja dostaw taniego towaru na rynki UE. Lokowanie produkcji tam gdzie najtaniej i jednocześnie bezpiecznie jest chwilową szansą dla polskiej gospodarki. Należy się spodziewać, że w przypadku unormowania sytuacji polityczno-gospodarczej w krajach Europy Wschodniej (głównie na Ukrainie) poszczególne korporacje będą bardziej zainteresowane lokowaniem produkcji w tamtym rejonie niż w Polsce.

KTN dysponując nowoczesnymi technologiami, nowoczesnymi metodami zarządzania firmami, elastycznością produkcji w istotny sposób oddziaływują na rynek pracy, poprzez zapotrzebowanie na specyficznych pracowników. Z jednej strony korporacje poszukują niewykwalifikowanych młodych pracowników, których można w krótkim czasie 
przyuczyć do wykonywania stosunkowo mało skomplikowanych czynności, natomiast z drugiej strony poszukują wysokiej klasy specjalistów, którzy będą stanowić dobrze opłacaną kadrę zarządzającą. Brak stabilizacji zawodowej wymusza zmiany w systemie kształcenia. Nowa gospodarka preferuje pracowników odpornych na stres, ogólnie wykształconych na poziomie wyższym, zdolnych do porzucenia jednego i szybkiego przyuczenia się do nowego zawodu.

Korporacje transnarodowe w coraz większym stopniu przerzucają koszty prowadzenia firmy na pracowników, poprzez rozwiązywanie z nimi umowy o pracę i zmuszanie ich do zakładania własnych firm. Pracownicy samozatrudniający się wykonują taką samą pracę jak dotychczas, z tą różnica, że są dodatkowo obciążeni kosztami prowadzenia firmy, tracąc dodatkowo prawo do płatnego urlopu wypoczynkowego. Płacąc zwyczajowo najniższą składkę na ubezpieczenie społeczne w przyszłości otrzymają znacznie niższe świadczenie emerytalne, niż przysługujące pracownikom etatowym wykonującym podobną pracę. W przypadku dużego zwiększenia liczby ubezpieczonych na takich warunkach może dojść do załamania się systemu emerytalno-rentowego w Polsce, ponieważ zabraknie środków na świadczenia. Innymi formami zatrudnienia preferowanymi przez korporacje są: praca czasowa, umowa terminowa, praca na zamówienie czy telepraca (ryc. 3). Za wyjątkiem telepracy pozostałe formy zatrudnienia są bardzo niekorzystne dla pracowników, gdyż nie gwarantują ciągłości zatrudnienia $\mathrm{i}$ - co się $\mathrm{z}$ tym bezpośrednio wiąże - ciągłości wynagrodzenia. Lansowane formy zatrudnienia z jednej strony zmuszają do zwiększenia wydajności pracy, natomiast $\mathrm{z}$ drugiej owocują proporcjonalnym spadkiem wynagrodzenia. Jedynie telepraca wydaje się być atrakcyjna dla pracownika. Jednak i w tym przypadku może ona być świadczona w niepełnym wymiarze godzin. Atutem telepracy jest z pewnością redukcja kosztów dojazdów do pracy.

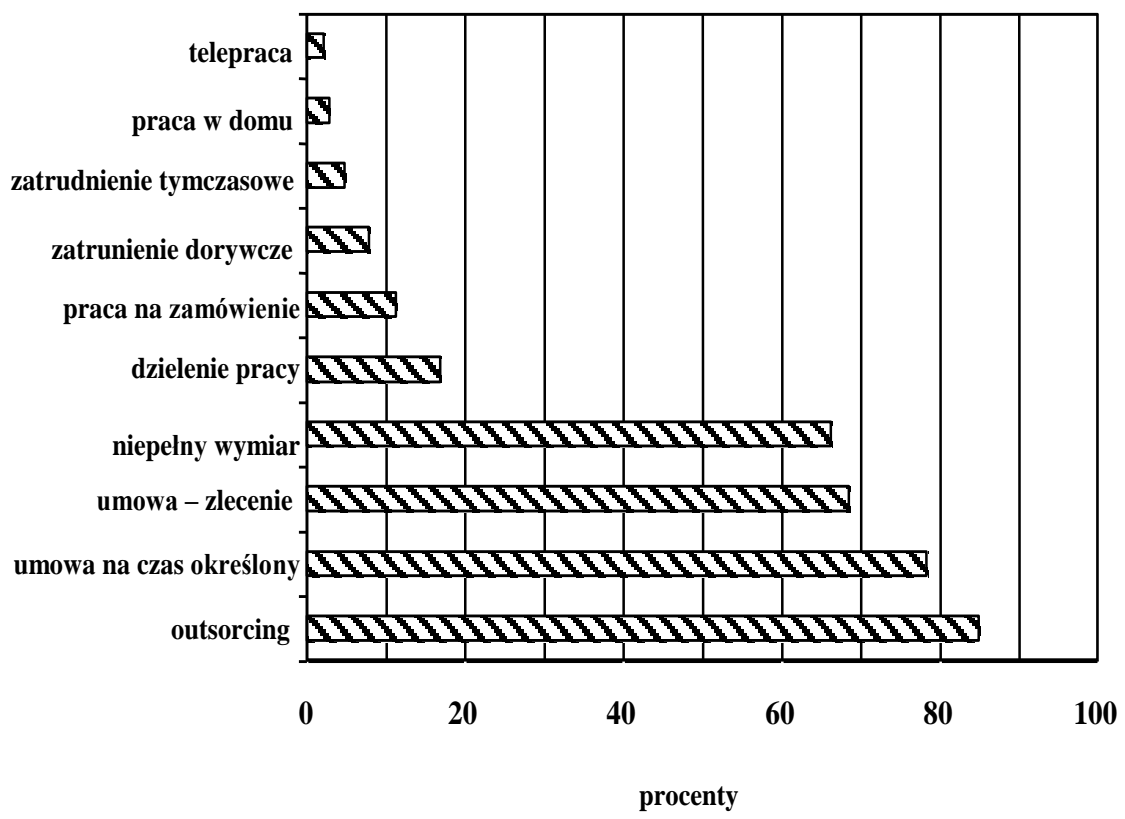

Ryc. 3. Niestandardowe formy zatrudnienia w badanych przedsiębiorstwach w Polsce w latach 2001-2002 
Źródło: Opracowanie własne na podstawie „Business Week”, 2002

Kolejną cechą mającą długofalowy wpływ na polską gospodarkę jest wyrównywanie warunków działania. Rozważając implikacje płynące $\mathrm{z}$ tej cechy należy uwzględnić globalną skalę rozpatrywanego zjawiska. Działalność korporacji przyczynia się do rozprzestrzeniania się idei „wolnego rynku”, która warunkuje ekspansję korporacji. Wyrównywanie warunków działania dotyczy jedynie kwestii formalno-prawnych, które w konsekwencji prowadzą do ujednolicenia reguł na arenie międzynarodowej poprzez eliminacje nieskutecznych procedur (Luttwak 2000). Jednak uwzględniając skalę korporacji należy stwierdzić, że lansowane zmiany służą przede wszystkim wielkiemu kapitałowi.

Niepokojącym zjawiskiem w polskiej gospodarce i nie tylko jest powszechność stosowania cen transferowych przez poszczególne korporacje. Za cenę transferową należy uznać każdą cenę, która została określona z wyłączeniem zasad rynkowych. Wagę zagadnienia podnosi fakt, że handel wewnątrzkorporacyjny potrafi osiągnąć nawet powyżej 50\% obrotów poszczególnych firm. Głównym celem stosowania cen transferowych jest wypompowywanie zysków poza granice państwowe. Proceder ten kwitnie w większości korporacji działających w Polsce. Doskonałym przykładem są korporacje handlowe, które w początkowych latach swojej działalności korzystały z wielu ulg podatkowych przyznawanych $\mathrm{w}$ nadziei, że w późniejszym okresie będą uiszczać podatek dochodowy. Pomimo iż okres ulgowy minął, to do budżetu nie wpływają szacowane dochody z podatku. Korporacje do perfekcji opanowały sztukę stosowania cen transferowych. Precyzyjnie manipulują kosztami w ten sposób, aby unikać podatku. Sprowadzając maszyny i urządzenia z zagranicy lub manipulując kosztami usług skutecznie omijają nasz system podatkowy poprzez wykazywanie chronicznych strat (tabela 2).

Tabela 2. Wyniki finansowe największych sieci handlowych w Polsce

\begin{tabular}{|r|l|c|c|c|}
\hline Lp. & Nazwa sieci & $\begin{array}{c}\text { Obroty netto } \\
\text { w mln euro } \\
(2000 \mathrm{r} .)\end{array}$ & $\begin{array}{c}\text { Liczba sklepów } \\
\text { (IX 2001 r.) }\end{array}$ & $\begin{array}{c}\text { Zysk przed } \\
\text { opodatkowaniem } \\
(2000 \mathrm{r} .)\end{array}$ \\
\hline 1. & Makro & 1632 & 18 & 2,6 \\
\hline 2. & Real & 744 & 24 & $-6,9$ \\
\hline 3. & Geant & 586 & 14 & $-2,0$ \\
\hline 4. & HIT & 439 & 13 & 0,1 \\
\hline 5. & Carrefour & 369 & 10 & $-2,6$ \\
\hline 6. & Auchan & 281 & 13 & $-1,1$ \\
\hline 7. & Tesco & 273 & 10 & $-9,9$ \\
\hline 8. & Leclerc & 122 & 8 & $-1,2$ \\
\hline 9. & Hypernowa & 107 & 9 & $-7,1$ \\
\hline 10. & Jumbo & 5 & $-2,6$ \\
\hline
\end{tabular}

Źródło: Commerzbank Securites

Reasumując, należy stwierdzić, że KTN intensywnie oddziaływują na polską gospodarkę, wspierają procesy umiędzynarodowienia produkcji oraz transformacji systemowej. Rosnąca podaż zagraniczna towarów i kapitału wpływa na stabilizację polskiej gospodarki. Jeżeli Polska pragnie znaleźć się w głównym nurcie przemian społeczno-gospodarczych współczesnego świata musi nie tylko zaakceptować funkcjonujące na naszym rynku KTN, 
ale przede wszystkim stwarzać korzystne warunki oraz wspierać proces tworzenia polskich korporacji. Działalność KTN na terenie Polski niesie ze sobą wiele zjawisk zarówno pozytywnych, jak i negatywnych. Nie wystarczy jednak mieć świadomość negatywnych konsekwencji, istnieje pilna potrzeba tworzenia szybkich regulacji prawnych minimalizujących negatywne zjawiska.

\section{Literatura}

Bielawski J., 2000, Wplyw globalizacji na wielostronnq wspótprace gospodarcza, „Sprawy Międzynarodowe" 1

Durka B., red., 2001, Inwestycje zagraniczne w Polsce. Raport jubileuszowy, IKiCHZ, Warszawa

Durka B., Chojna J., 2001, Polityka wobec inwestorów zagranicznych i bezpośrednie inwestycje zagraniczne $w$ Polsce $w$ latach 2000-2001, [w:] Zagraniczna polityka gospodarcza Polski 2000-2001, red. J. Kotyński, IKiCHZ, Warszawa

„Fortune” 23 july, 2001

Grzeszak A., Dziadul J., 2002, Ochota na Toyote, ,Polityka” nr 16 (2346)

Gwiazda A., 2000, Globalizacja i regionalizacja gospodarki światowej, Torun

Luttwak E., 2000, Turbokapitalizm, Wrocław

Thurow L., 1999, Cywilizacja zmian, „Wprost”, 11.04.

World Investment Report, New York 1999, s. 4-18, [w:] J. Bielawski, Wptyw globalizacji na wielostronna wspótprace gospodarczq, „Sprawy Międzynarodowe” 2000, 1

Zorska A., 2000, Ku globalizacji. Przemiany $w$ korporacjach transnarodowych $i w$ gospodarce światowej, Warszawa 